Published in Scottish Journal of Geology, 2013, Volume 49, 33-40.

Note that this version of the text does not include the Journal's editorial and proof

corrections

\title{
Regional geochemical patterns in south-east Scotland: source lithology, inheritance and glacial overprinting
}

\author{
P. Stone and A. A. McMillan \\ British Geological Survey, Murchison House, West Mains Road, Edinburgh EH9 3LA \\ psto@bgs.ac.uk
}

\section{Synopsis}

The Lower Palaeozoic, Southern Uplands terrane shows a NE-SW, strike-parallel coincidence of regional geochemical lineaments defined from stream sediment data, and major, lithostratigraphically significant structures. West of Moffat, Silurian strata of the Gala and Hawick groups are divided by geochemical lineaments coincident with the Laurieston Fault. East of Moffat the geochemical lineaments diverge towards the north-east with Gala-type regional geochemistry (high $\mathrm{Sr}$ and $\mathrm{Ba}$, low $\mathrm{CaO}$ ) to the north of the Moffat Valley Fault, whilst Hawick-type regional geochemistry (low $\mathrm{Sr}$ and $\mathrm{Ba}$, high $\mathrm{CaO}$ ) continues to the south of the Laurieston Fault; between the faults lies the recently defined Ettrick Group. Beyond the eastern end of the Lower Palaeozoic outcrop its geochemical lineaments extend across the unconformable cover of Devonian 'Old Red Sandstone'. This is partly a drainage catchment effect, but two other possible explanations are considered: a localized derivation of the Devonian clastic rocks such that they inherit the compositional patterns of the underlying Lower Palaeozoic sandstones, or a geochemical signature imposed by glacial deposits derived from the Lower Palaeozoic outcrop. The local effect of glacial dispersion is confirmed by the distribution of $\mathrm{TiO}_{2}$; anomalously high levels associated with Carboniferous mafic lavas have been transported north-east across the low- $\mathrm{TiO}_{2}$ Carboniferous sedimentary rocks of the Tweed Basin. 


\section{Introduction}

The Southern Uplands terrane is an imbricate thrust belt of turbidite-facies strata that developed from the late Ordovician to the mid-Silurian along the Laurentian margin of the Iapetus Ocean. The Southern Upland Fault forms the NW margin of the terrane, which is now the southernmost tectonic block of the Scottish Caledonides and lies immediately to the north of the Iapetus Suture. Internally, the terrane comprises a number of fault-defined tracts, elongated NE-SW parallel to strike, in most of which the bedding is steeply inclined and youngs towards the NW; in contrast, the age of the individual tracts becomes sequentially younger towards the SE (Floyd 2001 and references therein). The structural relationships of the tract are interpreted in terms of its development as a supra-subduction zone accretionary complex (Leggett et al. 1979; Leggett 1987). Despite much debate of this issue, an accretionary origin for most of the terrane is confirmed by the thermal characteristics of the precursor sedimentary basin (Stone \& Merriman 2004). In south-east Scotland, the Silurian and Ordovician strata of the Southern Uplands accretionary thrust belt are overlain, with marked angular unconformity, by Devonian clastic rocks of ‘Old Red Sandstone’ lithofacies and associated andesitic lavas (Figure 1). This assemblage is in turn succeeded by early Carboniferous rocks comprising mafic lavas and a lithologically mixed sedimentary sequence (Smith 1967). The regional geology is summarised and described by Oliver et al. (2002) and Stone et al. (2012).

In this paper we describe the regional geochemical features that arise from the contrasting Lower and Upper Palaeozoic outcrops, and discuss the reasons for their different geological to geochemical relationships. The differences became apparent during British Geological Survey (BGS) projects in SE Scotland in which the regional geochemical patterns were utilised as an aid to geological mapping. They illustrate contrasting interactions between geology and erosive processes, independently confirm glacial distribution, and may have broader application in the interpretation of regional, stream-sediment geochemistry. The geochemical data utilised are illustrated and statistically quantified in the BGS's regional geochemical atlas for Southern Scotland (BGS 1993) and form part of G-BASE, a comprehensive overview of 
the distribution of elements in the surface environment of Britain. The data were derived from the analysis of the $<150$ micron fraction in stream sediment samples systematically collected at a density of approximately one per $1.5 \mathrm{~km}^{2}$. A range of about 30 elements and major oxides is available for southern Scotland. The methods of collection, analysis and data processing that have been employed are detailed in the geochemical atlas.

Across the Lower Palaeozoic outcrop the fault-defined bedrock tracts are extended in the NESW along-strike direction, but are relatively narrow in the NW-SE cross-strike direction; individual tracts may range up to several kilometres in width but some pinch-out laterally. The tract pattern is mirrored in the element distribution seen in the stream sediment geochemistry, with zones of high and low concentration alternating to create a NE-SW "stripy" effect. The steepest concentration gradients in the stream sediment data can be consolidated into geochemical lineaments that may coincide with tract-bounding faults, though different elements show different distribution patterns. In some cases, lineaments appear to identify cryptic compositional contrasts in the bedrock that are not otherwise recognised. These may either relate to different stratigraphical sandstone units within a single tract, or allow a tract that had previously been regarded as a single entity to be structurally divided into two or more tracts. However, we stress that the relatively low sampling density means that the positions of the identified lineaments should be regarded as indicative rather than precise. It should also be noted that different elements may be responding to different influences, so much so that some lineaments appear to intersect.

The regional tectono-stratigraphical significance of the geochemical patterns has been discussed by Stone et al. $(1999,2004)$ who have identified two element assemblages as being of particular value in tracking geologically-controlled changes in sediment composition: the basic-ultrabasic elements (Cr-Ni-Mg-V-Ti), and the feldspar association (Rb-Sr-K-Ba). However, the direct spatial associations between the patterns of element distribution in stream sediment and changes in the underlying bedrock outcrop do not necessarily mean that the two media have the same compositions. The significances of relative enhancement or depletion from rock to sediment have been explored by Stone et al. $(2003,2006)$. 


\section{The influence of glaciation}

Northern Britain has been extensively glaciated but across the Lower Palaeozoic outcrop of the Southern Uplands terrane there is still a high level of spatial coincidence between the outcrop patterns of the different rock types and the element distribution patterns in the stream sediments, the markedly linear pattern of element distribution in sediment mirroring the NESW trend of the bedrock tracts (BGS 1993). The implication is that stream sediment composition reflects the Lower Palaeozoic bedrock geology and that glacial smearing effects are minimal (Stone et al. 2006 and references therein). Stone et al. (1999) speculated that the apparently limited glacial dispersion within the Lower Palaeozoic outcrop might indicate the presence of a cold-based ice sheet, but there is a mitigating factor to be considered in the eastern part of the Southern Uplands. Across the Southern Uplands region generally, ice radiated from dispersal centres in the Galloway and Moffat hills (Stone et al. 2012, figure 56), thence flowing for the most part obliquely across the NE-SW trend of the geology and regional geochemistry. However, in the east of the Southern Uplands the principal ice flow direction during glaciation was towards the north-east, emanating from the Moffat Hills dispersal centre, and thence running parallel to the strike of the bedrock tracts. Under these circumstances glacial redistribution may not be apparent within the Lower Palaeozoic outcrop but should cause a discernable effect at its eastern margin where the ice stream passed onto the outcrop of an unconformable cover of Upper Palaeozoic rocks. Such an effect is indeed visible in the Southern Uplands data, but not emanating directly from a Lower Palaeozoic source.

At the eastern end of the Southern Uplands the Hawick Group is unconformably overlain by Devonian 'Old Red Sandstone’ strata, the Reston and Stratheden groups, which are in turn overlain by Carboniferous mafic lavas and sedimentary rocks of the Inverclyde Group. These Upper Palaeozoic rocks form relatively low-lying ground: to the north the Lower Palaeozoic, Gala Group outcrop continues to form the Lammermuir Hills whilst to the south the Cheviot massif is underpinned by Devonian andesitic lavas and a granite pluton (Figure 1). The effect of this geologically-controlled topography was to channel the Southern Uplands ice stream into a strongly north-eastward flow (Everest et al. 2006) that is well illustrated by the array of streamlined megadrumlins that runs through the Tweed Basin and fans out across The Merse 
of Berwickshire (Figure 2). The district is now extensively till-covered and thicknesses of Late Devensian tills within the drumlinised district may typically range from 5 to $10 \mathrm{~m}$. The tills of the Tweed Basin, assigned to the Norham Till Formation of the Borders Glacigenic Group (McMillan in Stone et al. 2012) are generally matrix-supported, sandy diamictons with clasts derived from the local sedimentary and volcanic rocks of the Inverclyde and Stratheden groups, together with Devonian volcanic and intrusive rocks (basalt, andesite) of the Cheviot Hills and Lower Palaeozoic sandstone and siltstone of the Southern Uplands.

The ice flow direction and associated extensive till cover has influenced the regional geochemical distributions with element abundances characteristic of the Carboniferous mafic lavas smeared eastward across the adjacent outcrop of sandstone, mudstone and limestone (the Inverclyde Group) in the Tweed Basin. The most striking effects are seen in titanium (as $\left.\mathrm{TiO}_{2}\right)$ with a similar, though less intense distribution pattern shown by vanadium (V), a geochemical associate of titanium. The titanium distribution pattern (Figure 3) shows the anticipated high levels of $\mathrm{TiO}_{2}$ over the Carboniferous basaltic lava outcrop (note that the Devonian lavas of Cheviot are more andesitic and so lower in titanium) but also shows these high levels extending north-eastward across the Inverclyde Group outcrop where they would not be expected. The $\mathrm{TiO}_{2}$ anomaly is concentrated across the northern part of the Inverclyde Group outcrop, which suggests that the southern part of the outcrop was perhaps crossed by ice emanating from Cheviot that did not introduce high-titanium detritus. The apparent southwestward extension of the anomaly onto lower Palaeozoic strata, in opposition to the ice-flow direction, in fact coincides with a small outlier of the Carboniferous lavas. This outlier is presumably a relic of a more extensive lava cover, now eroded and weathered, which may still influence the composition of the local regolith. In this respect it is worth noting that survival or extension of the $\mathrm{TiO}_{2}$ anomaly could be influenced by the susceptibility of the lavas to deep weathering under humid Tertiary conditions. A thick regolith would be expected to have formed, much of which would have been readily stripped and redistributed during subsequent glaciation.

\section{The Lower Palaeozoic outcrop: geology}


Within the Southern Uplands accretionary thrust belt (Figure 1), the northern tracts of Caradoc and Ashgill (Upper Ordovician) age comprise the Leadhills Supergroup (Floyd 1996) for which the Orlock Bridge Fault (Anderson and Oliver 1986) forms the southern margin. In the south-west of the Southern Uplands, southwards from the Orlock Bridge Fault and as far as the Balmae Burn Fault, a series of Llandovery to Wenlock (Lower to Middle Silurian) tracts forms first the Gala Group (Llandovery) and then the Hawick Group Llandovery to Wenlock), separated from each other by the Laurieston Fault (Akhurst et al. 2001). In the central and eastern parts of the Southern Uplands, the Llandovery tracts of the Ettrick Group intervene between the Gala and Hawick groups, and broaden north-eastward (Figure 1). To the south of the Hawick Group, the Riccarton Group comprises Wenlock (Middle Silurian) tracts.

The Ettrick Group was first utilised for the BGS (2009) 1:50 000 scale maps for the Moffat and Ettrick districts (Scotland sheets 16W, \& 16E) based largely on geological mapping by R. P. Barnes, though two of its component formations had been included within the Hawick Group on the previously published Lochmaben map (Scotland sheet 10W: 2007). The introduction of the Group helped resolve the long-standing interpretational difficulty posed by the regional relationship between the Gala and Hawick groups. In the western part of the Southern Uplands the Laurieston Fault forms a relatively well-defined boundary between them, but eastwards the distinction is less clear and is further complicated by additional structural imbrication which has the effect of progressively broadening the Llandovery outcrop. The traditional solution has been to place the Gala-Hawick boundary at the northern limit of carbonate-rich wacke-sandstones thought to be characteristic of the Hawick Group (e.g. Floyd 2001). This extended the Laurieston Fault to the north-east, more-or-less along the line of the lower Ettrick Valley (Figure 3). By default, the rocks to the north of this line were assigned to the Gala Group but regional assessment of the G-BASE data identified the Moffat Valley Fault as a major compositional boundary with an abrupt change across it in Rb/Sr ratio as a key feature (Stone et al. 1993). The strata contained between the lower Ettrick Water valley (the Laurieston Fault) and the Moffat Water valley (The Moffat Valley Fault) were largely those forming the eastward-broadening imbricate zone and as such might not have been directly represented farther west. Accordingly, Stone \& Evans (2001) referred them to the Buckholm Formation, adopting lithostratigraphy proposed farther east in the Gala Water 
area by Kassi \& Weir (1993); older literature relates these strata to a Garnetiferous Group (Walton 1955) although the boundaries are not everywhere consistent. With $\mathrm{Rb} / \mathrm{Sr}$ ratios similar to those of the Hawick Group, but without the characteristic high carbonate content of that group, the Buckholm Formation was potentially transitional between the two established groups. The more recent formalisation of the lithostratigraphy assigned the transitional strata to four of the five formations of the newly-defined Ettrick Group (Barnes and Stone in Stone et al. 2012). At its southern margin, some strata are incorporated in the Ettrick Group that traditionally have been placed within the Hawick Group. This undermines the status of the Laurieston Fault as previously defined to the east of Moffat, but for simplicity its usage will be continued here in the sense of the fault dividing the Ettrick and Hawick groups.

\section{The Lower Palaeozoic outcrop: principal geochemical lineaments}

The principal structural lineaments dividing the Gala, Ettrick and Hawick groups (Figure 1) are well defined by steep gradients in the countoured distribution of key indicator elements in the G-Base stream sediment data; $\mathrm{Sr}, \mathrm{Ba}$ and $\mathrm{Ca}($ as $\mathrm{CaO}$ ) are particularly effective. In the following discussion of these features, the element abundance values cited are from Stone et al. (2006). In deriving their summary statistics from the regional geochemical data, Stone et al. excluded data pertaining to the strata between the Moffat Valley Fault and the Laurieston Fault (their extension of the Buckholm Formation, now within the Ettrick Group) since at that time their association was unclear.

\section{Calcium}

Traditionally, high calcium carbonate content has been taken as characteristic of the Hawick Group. As now defined, Hawick Group wacke-sandstones contain between about 5\% and 15\% $\mathrm{CaO}$, and though $\mathrm{CaO}$ content of Ettrick Group wackes ranges up to about 8\%, and Gala Group wackes to about 6\%, the markedly higher $\mathrm{CaO}: \mathrm{SiO} 2$ ratio of the Hawick Group rocks is distinctive (Stone et al. 2012, figure 20). The $\mathrm{CaO}$ abundance in the Hawick Group rocks is reflected in the stream sediment (and also the bicarbonate content of stream water, see BGS, 1993, p. 26), with uniformly high levels over the Hawick Group to the south of the Laurieston Fault; $\mathrm{CaO}$ concentration in the sediment there is generally $>0.5 \%$. A steep geochemical 
gradient coincides with the fault, defining a lineament north of which the $\mathrm{CaO}$ abundance in stream sediment is much lower than to the south, with concentration generally $<0.3 \%$. At the eastern limit of the Lower Palaeozoic outcrop, around Melrose, the geochemical lineament diverges a little from the mapped line of the fault (Figure 3), and though both fault and lineament swing south, the lineament strays north of the fault. An explanation for the apparent mismatch might invoke the strong, linear ice flow evident between Melrose and Kelso in Figure 2. This ice flow direction coincides with the regional strike of the Lower Palaeozoic strata seen to the south-west of Melrose, where the lineament and the Ettrick-Hawick boundary fault have closely parallel alignment; hence the extension of the regional geochemical pattern north-eastward might simply arise from glacial transport overprinting the local geological boundary. Alternatively, the discrepancy might suggest that the geological interpretation would benefit from reassessment, and an additional complication in this area arises from the drainage pattern. Near Melrose, the southward-flowing Leader Water (draining Lauderdale) joins the River Tweed and might be expected to have carried an 'Ettrick Group' signature further south than the bedrock outcrop would predict. However, that should push the $\mathrm{CaO}$ lineament to the south of the geological boundary, whereas the opposite effect is seen.

Further east, beyond the eastern limit of the Lower Palaeozoic outcrop, the geochemical gradient continues, apparently uninterrupted, as a strong and unambiguous lineament across the unconformably overlying ‘Old Red Sandstone’ sequence. The significance of this apparently inherited feature is discussed more fully later in this paper.

\section{Strontium and Rubidium}

Across the western part of the Southern Uplands terrane the Laurieston Fault coincides with a well-defined geochemical lineament, a steep gradient in strontium abundance from relatively high values in stream sediment over the Gala Group to relatively low values over the Hawick Group. East of the Permian outlier at Moffat the geochemical lineament diverts from the Laurieston Fault to coincide with the Moffat Valley Fault which separates the Gala Group (Sr in wacke-sandstone mostly >150 ppm) from the Ettrick Group ( $\mathrm{Sr}$ in wacke-sandstone mostly $<175$ ppm). Subordinate Sr lineaments (Figure 3) presage the subdivision of the Ettrick Group into component formations. Further east the clarity of the "Moffat Valley" Sr lineament is 
reduced, but it appears to cross the 'Great Conglomerate’ Lower Old Red Sandstone outlier of Lauderdale and continue north-east, beyond the outlier, across the Lammermuir Hills outcrop of Silurian strata. All the strata of that inlier are traditionally assigned to the Gala Group, but it is probable that those in the southern half should be associated with the newly-defined Ettrick Group (Figure 1). A further north-eastward extrapolation of the Sr lineament takes it across the outcrop of 'Great Conglomerate' south of Dunbar (Davies et al. 1986), and to the north of the inlier of Silurian rocks at Coldingham Moor. The rocks of the Coldingham Moor inlier (Greig 1988) have been previously assigned to the Gala Group (e.g. Floyd 2001), but more probably lie within the eastward extension of the Ettrick Group (Figure 1).

If $\mathrm{Rb}$ and $\mathrm{Sr}$ are hosted largely in feldspars they might be expected to show an inverse distribution pattern, but this is not seen over the Gala Group where exceptionally high and varied Sr levels in the stream sediments (median $=132 \mathrm{ppm}$ ) are matched by relatively high Rb levels (median $=118$ ppm). Sediment derived from the Hawick Group shows more of a 'feldspar' composition with Rb levels (median $=119 \mathrm{ppm}$ ) very similar to those seen in association with the Gala Group, but with much reduced Sr (median = $73 \mathrm{ppm}$ ). Hence the difference in the $\mathrm{Rb} / \mathrm{Sr}$ ratio seen across the Moffat Valley Fault may well be entirely due to a marked decrease in Sr abundance from the Gala-derived sediment to the Ettrick- and Hawickderived sediment, whilst Rb remains virtually unchanged (Stone et al. 2006).

\section{Barium}

On the regional scale, Barium is another element that may well be held in feldspars, but with localized intense elevations probably due to mineralisation. There is a well-established zone of relatively high Ba levels in stream sediments that coincides with the Gala Group outcrop to the north of the Laurieston and Moffat Valley faults (median = $781 \mathrm{ppm}$ ) in the central part of the Southern Uplands. This contrasts with relatively low levels of Ba in sediment across the Hawick Group outcrop to the south of the Laurieston Fault (median $=480 \mathrm{ppm}$ ). Between the two faults, across the outcrop of the Ettrick Group, the Ba levels are broadly intermediate but with abrupt local variations consistent with the internal heterogeneity of the group. 
The geochemical lineaments defined by $\mathrm{Ba}$ abundance approximate to those defined by strontium, though there are sufficient differences to suggest structural and/or stratigraphical complications within the Ettrick Group. In the western part of the Southern Uplands terrane, the Laurieston Fault coincides with the steep geochemical gradient between high $\mathrm{Ba}$ abundance over the Gala Group to the north, and relatively lower Ba abundance over the Hawick Group to the south. Between the Permian outliers at Dumfries and Moffat the Ba lineament drifts north of the Sr lineament, but east of Moffat they recombine to give a strong association with the Moffat Valley Fault. Further north-east, the Ba lineament is less well defined, but seems to drift south of the strontium lineament as it runs towards and across the Lower Devonian, Great Conglomerate Formation outlier in Lauderdale, and the Lammermuir Hills Lower Palaeozoic outcrop. The likelihood of the Lammermuir outcrop containing strata from both the Gala and Ettrick groups is nonetheless reinforced.

The status of the geochemical lineaments

The distribution of geochemical lineaments across the Southern Uplands Lower Palaeozoic terrane confirms the following:

- In the western Southern Uplands the line of the Laurieston Fault is the northern margin of strata high in $\mathrm{CaO}$ and traditionally regarded as Hawick Group. A reassessment of the Laurieston Fault may be appropriate further east if it is to be regarded as the boundary structure between the Ettrick and Hawick groups. There, for part of its length, the fault coincides with the lower reaches of the Ettrick Water valley where it has been identified at outcrop in Buck Cleuch [NT 334 145].

- The north-eastward-broadening zone of strata between the diverging Moffat Valley and Laurieston faults has compositional characteristics that are distinct from both those of the Hawick Group to the south and the archetypal Gala Group to the north. This intermediate zone has been previously associated with the Buckholm Formation (Kassi \& Weir 1993; Stone \& Evans 2001) but has more recently been described as the Ettrick Group (Barnes \& Stone in Stone et al. 2012). The Ettrick Group’s proposed division into several formations is supported by its likely geochemical heterogeneity as reflected in the stream sediment data. 
- The southern margin of the Gala Group, as defined by the coincidence of Sr and Ba lineaments along the Moffat Valley Fault, can be extrapolated north-east across the Lammermuir Hills outcrop, hitherto regarded as comprising Gala Group strata but divided by the geochemical lineaments such that only the northern sector is securely assigned to that group.

- North-eastward extrapolation of the Sr lineament takes it north of the Coldingham Moor inlier of Silurian rocks. These strata have been previously described as Gala Group, but are more appropriately included within the newly-defined Ettrick Group.

\section{The Upper Palaeozoic outcrop: inheritance of geochemical lineaments?}

An unexpected feature of the principal geochemical lineaments in the Southern Uplands terrane is that, at its eastern end, they continue uninterrupted across the unconformable cover of Devonian, 'Old Red Sandstone’ strata. The Lower Devonian, Great Conglomerate Formation (Reston Group) outlier in Lauderdale is crossed by the $\mathrm{Sr}$ and Ba lineaments and divided neatly into halves with higher abundances of these elements to the north, and lower abundances to the south, although the Ba lineament crosses slightly to the south of the $\mathrm{Sr}$ lineament. An even more striking example is provided by the $\mathrm{CaO}$ lineament, which extends north-eastward as a strong feature across the Upper Devonian, Stratheden Group outcrop of south Lauderdale, where there is no coincidental stratigraphical or structural explanation. Three factors might influence this apparent inheritance of a Lower Palaeozoic feature by the unconformable cover of 'Old Red Sandstone’ strata: the drainage (and hence sampling) pattern, glacial transport, and localized sedimentary recycling.

The effects of glacial transport may theoretically have influenced both the Lower and Upper Devonian examples since a strong, strike-parallel ice flow extended from the Lower Palaeozoic outcrop of the Southern Uplands north-eastward across the 'Old Red Sandstone' outcrops. However, in the case of the Great Conglomerate Formation outlier in Lauderdale, an alternative explanation seems more likely. There, geochemical samples were collected from tributary streams flowing mainly from SW to NE and sourced in the Lower Palaeozoic outcrop (British Geological Survey 1993, figure 2). The tributary streams flowed into the Leader Water, which drains southward along the axis of the outlier, but few samples were acquired 
from the Leader Water itself. In effect, streams were sampled that carried a Lower Palaeozoic geochemical signature northeastwards, parallel to the strike of the Lower Palaeozoic strata, across the unconformably overlying Upper Palaeozoic strata. The resulting geochemical pattern is thus most probably an artefact of the drainage and sampling regime. This is also the likely explanation for a similar effect seen in the Permian outlier to the west at Moffat, but such an explanation is not valid for the $\mathrm{CaO}$ lineament in the Upper Devonian, Stratheden Group outcrop of southeast Scotland, which cuts obliquely across the sampled drainage catchments.

The most likely explanation for the $\mathrm{CaO}$ lineament across the Upper Devonian, Stratheden Group outcrop centred on Jedburgh (Figures 1 and 3) seems to us to be by direct inheritance through sedimentary recycling. Though glacial transport was most probably responsible for the smearing of the $\mathrm{TiO}_{2}$ distribution pattern, as described earlier, the glacial flow direction evident from the orientation of the regional drumlin swarm (Figure 2) diverges from the $\mathrm{CaO}$ lineament as they are respectively traced towards the northeast. Hence it seems unlikely that glacial transport would have influenced the lineament's formation and maintained the precise linearity and orientation of the Lower Palaeozoic $\mathrm{CaO}$ abundance gradient for a distance of at least $20 \mathrm{~km}$ beyond the end of the Lower Palaeozoic outcrop. But we acknowledge that a combination of effects is possible in the western part of the Stratheden Group outcrop in view of the likelihood that glacial transport has locally overprinted the Lower Palaeozoic geology around Melrose, as discussed above.

Though not showing a definitive relationship, the sedimentology of the Stratheden Group may influence any geochemical inheritance through sedimentary recycling. Leeder (1973) proposed that the essentially fluvial Devonian strata of the Jedburgh area were deposited in an enclosed, 'interior' basin fed on its western side, between the Solway Firth and Hawick, principally by a river system flowing from the south-west and introducing detritus sourced in the Galloway: Lower Palaeozoic wacke-sandstone, granite and Caledonian dyke rocks. Further north-east, between Jedburgh and Berwick, Leeder (1973, 1976), citing the evidence of Smith (1967), concluded that southwesterly-directed currents predominated, thus supporting his concept of an interior basin, although this 
model was disputed by Paterson et al. (1976) who favoured an eastward flowing river system. Despite the undoubted introduction of some 'foreign' sediment, the persistence of the $\mathrm{CaO}$ geochemical lineament strongly suggests that much of the material forming the Stratheden Group 'Upper Old Red Sandstone’ lithologies of the Tweed Basin was derived from the local Silurian sandstones. This would allow the compositional characteristics of those Silurian sandstones to be carried forward into the overlying, Devonian sandstones and conglomerates so that the 'Lower Palaeozoic' regional geochemical pattern is preserved in the younger rocks.

\section{Conclusions}

Within the Lower Palaeozoic Southern Uplands terrane regional geochemical lineaments are defined by steep gradients in element abundance in stream sediments. The strike-parallel persistence of certain of these lineaments, notably for $\mathrm{Sr}, \mathrm{Ba}$ and $\mathrm{CaO}$, and their association in places with well-defined and stratigraphically significant structures, is particularly helpful in the Silurian tracts of the terrane, which lack readily identifiable lithological discriminators. The geochemical lineaments define a north-eastward divergence from the Moffat area of Galatype compositions to the north of the Moffat Valley Fault in contrast to Hawick-type compositions to the south of the Laurieston Fault. Between these structures, strata now defined as the Ettrick Group are of variable, though broadly intermediate composition; the proposed subdivision of the group being supported by its internal geochemical heterogeneity. Strong Sr and $\mathrm{Ba}$ lineaments both suggest that the southern margin of the Gala Group (sensu stricto) extends north-east from the Moffat Valley towards Lauder and the central 'waist' of the Lower Devonian ‘Great Conglomerate’ outlier.

At the eastern end of the Southern Uplands terrane, the regional geochemical lineaments continue without deviation or dilution across the unconformable cover of Devonian 'Old Red Sandstone'. For the Sr and Ba lineaments, their extension across the Lower Devonian Great Conglomerate Formation outcrop in Lauderdale seems likely to be an artifact of the drainage sampling pattern. However, this effect would not explain the more extensive continuation of the $\mathrm{CaO}$ lineament across the Upper Devonian (Stratheden Group) outcrop. That feature is 
thought to arise from localized derivation of much of the sediment forming the Devonian clastic rocks such that they inherit the compositional patterns of the underlying Lower Palaeozoic sandstones. Glacial dispersion is apparently negligible over much of the Lower Palaeozoic outcrop, though in the east its effect may have been minimised by generally strikeparallel ice flow. Beyond the margin of the Lower Palaeozoic outcrop in the Merse of Berwickshire the effect of ice movement towards the north-east is apparent in the distribution of $\mathrm{TiO}_{2}$ abundances, with the high levels derived from Carboniferous mafic lavas extended north-east across the outcrop of the Inverclyde Group sandstone-mudstone-limestone assemblage.

\section{Acknowledgments}

We thank Neil Breward for discussion and processing of geochemical images, Rob Barnes for discussion of Southern Uplands geology, particularly with reference to the Ettrick Group, and Clive Auton and Jez Everest for helpful reviews of this paper's early drafts; the efforts of the two referees are also gratefully acknowledged. The figures were prepared by Craig Woodward. The paper is published by permission of the Executive Director, British Geological Survey (NERC).

\section{References}

Akhurst, M.C., McMillan, A.A., Kimbell, G.S., Stone, P. \& Merriman, R.J. 2001. Silurian subduction-related assembly of fault-defined tracts at the Laurieston Fault, Southern Uplands accretionary terrane, Scotland, UK. Transactions of the Royal Society of Edinburgh: Earth Sciences, 91, 435-446.

Anderson, T.B. \& Oliver, G.J.H. 1986. The Orlock Bridge Fault: a major Late Caledonian sinistral fault in the Southern Uplands terrane, British Isles. Transactions of the Royal Society of Edinburgh: Earth Sciences, 77, 203-222. 
British Geological Survey. 1993. Regional geochemistry of southern Scotland and part of northern England. British Geological Survey, Keyworth, Nottingham.

British Geological Survey. 2009. Moffat and Ettrick. Scotland. Sheets 16 West and 16 East. Bedrock Geology. 1:50 000. British Geological Survey, Keyworth, Nottingham.

Davies, A., McAdam, A.D. \& Cameron, I.B. 1986. Geology of the Dunbar district. Memoir of the British Geological Survey, Sheet 33E and part of Sheet 41 (Scotland).

Everest, J., Bradwell, T. \& Golledge, N. 2006. Subglacial landforms of the Tweed palaeo-ice stream. Scottish Geographical Journal, 121, 163-173.

Floyd, J.D. 1996. Lithostratigraphy of the Ordovician rocks in the Southern Uplands: Crawford Group, Moffat Shale Group, Leadhills Supergroup. Transactions of the Royal Society of Edinburgh: Earth Sciences, 86, 153-165.

Floyd, J.D. 2001. The Southern Uplands Terrane: a stratigraphical review. Transactions of the Royal Society of Edinburgh: Earth Sciences, 91, 349-362.

Greig, D.C. 1988. Geology of the Eyemouth district. Memoir of the British Geological Survey, Sheet 34 (Scotland).

Kassi, A.M. \& Weir, J.A. 1993. Depositional and geotectonic history of the Gala area, eastern Southern Uplands, Scotland. Transactions of the Royal Society of Edinburgh: Earth Sciences, 84, 161-173.

Leeder, M.R. 1973. Sedimentology and palaeogeography of the Upper Old Red Sandstone in the Scottish Border Basin. Scottish Journal of Geology, 9, 117-145.

Leeder, M.R. 1976. Upper Old Red Sandstone Paleogeography - Reply. Scottish Journal of Geology, 12, 90-91. 
Leggett, J.K. 1987. The Southern Uplands as an accretionary prism: the importance of analogues in reconstructing palaeogeography. Journal of the Geological Society, London, 144, 737-752.

Leggett, J.K., McKerrow, W.S. \& Eales, M.H. 1979. The Southern Uplands of Scotland: a Lower Palaeozoic accretionary prism. Journal of the Geological Society, London, 136, 755770.

Oliver, G.J.H., Stone, P. \& Bluck, B.J. 2002. The Ballantrae Complex and Southern Uplands terrane. In Trewin, N.H. (ed.) The Geology of Scotland. The Geological Society, London, 167200.

Paterson, I.B, Browne, M.A.E. \& Armstrong, M. 1976. Upper Old Red Sandstone Paleogeography. Scottish Journal of Geology, 12, 89.

Smith, T.E. 1967. A preliminary study of sandstone sedimentation in the Lower Carboniferous of the Tweed Basin. Scottish Journal of Geology, 3, 282-305.

Stone, P \& Evans, J.A. 2001. Silurian provenance variation in the Southern Uplands terrane, Scotland, assessed using neodymium isotopes and linked with regional tectonic development. Transactions of the Royal Society of Edinburgh: Earth Sciences, 91, 447-455.

Stone, P. \& Merriman, R.J. 2004. Basin thermal history favours an accretionary origin for the Southern Uplands terrane, Scottish Caledonides. Journal of the Geological Society, London, 161, 829-836.

Stone, P., Green, P.M., Lintern, B.C., Simpson, P.R. \& Plant, J.A. 1993. Regional geochemical variation across the Iapetus Suture zone: tectonic implications. Scottish Journal of Geology, 29, 113-121. 
Stone, P., Plant, J.A., Mendum, J.R. \& Green, P. 1999. A regional geochemical assessment of some terrane relationships in the British Caledonides. Scottish Journal of Geology, 35, 145156.

Stone, P., Breward, N. \& Merriman, R.J. 2003. Mineralogical controls on metal distribution in stream sediment derived from the Caledonides of the Scottish Southern Uplands and English Lake District. Mineralogical Magazine, 67, 325-338.

Stone, P., Breward, N., Merriman, R.J. \& Plant, J. A. 2004. Regional geochemistry of cryptic geology: variations in trace element distribution across the Southern Uplands terrane, Scotland. Applied Earth Science (Transactions of the Institution of Mining and Metallurgy B), 113, B43-B57.

Stone, P., Breward, N., Merriman, R.J. \& Barnes, R.P. 2006. The interpretation and application of regional geochemistry: lessons from the Paratectonic Caledonides. Scottish Journal of Geology, 42, 65-76.

Stone, P., McMillan, A.A., Floyd, J.D., Barnes, R.P. \& Phillips, E.R. 2012. British Regional Geology: South of Scotland (Fourth edition). Keyworth, Nottingham: British Geological Survey. 247 pp.

Walton, E. K. 1955. Silurian greywackes in Peebleshire. Proceedings of the Royal Society of Edinburgh, B65, 327-357.

\section{Figure Captions}

1. Outline geological map showing the distribution of the principal rock units in the north-eastern part of the Scottish Southern Uplands. Geological linework from Stone et al. (2012). 
2. Streamlined megadrumlins across the Tweed Basin demonstrating the movement direction of a fast-flowing ice stream, with grey-scale shaded topography illuminated from the north-west. The drumlins are particularly well seen to the north-east of Kelso as elongated ellipses fading to the north-east. The NE-directed ice flow that they indicate swings to become ESE-directed to the south of Berwick. This illustration is based on a NEXTMap Digital Terrain Model (5 m vertical resolution) (NEXTMap Britain elevation data from Intermap Technologies).

3. Some of the principal geochemical lineaments from the eastern part of the Southern Uplands Lower Palaeozoic outcrop and their north-eastward extension. Also shown is the north-eastward glacial transport of high $\mathrm{TiO}_{2}$ abundances derived from the outcrop of Carboniferous mafic lavas coincident with the apex of the high $\mathrm{TiO}_{2}$ "horseshoe". Geological linework from Stone et al. (2012). 


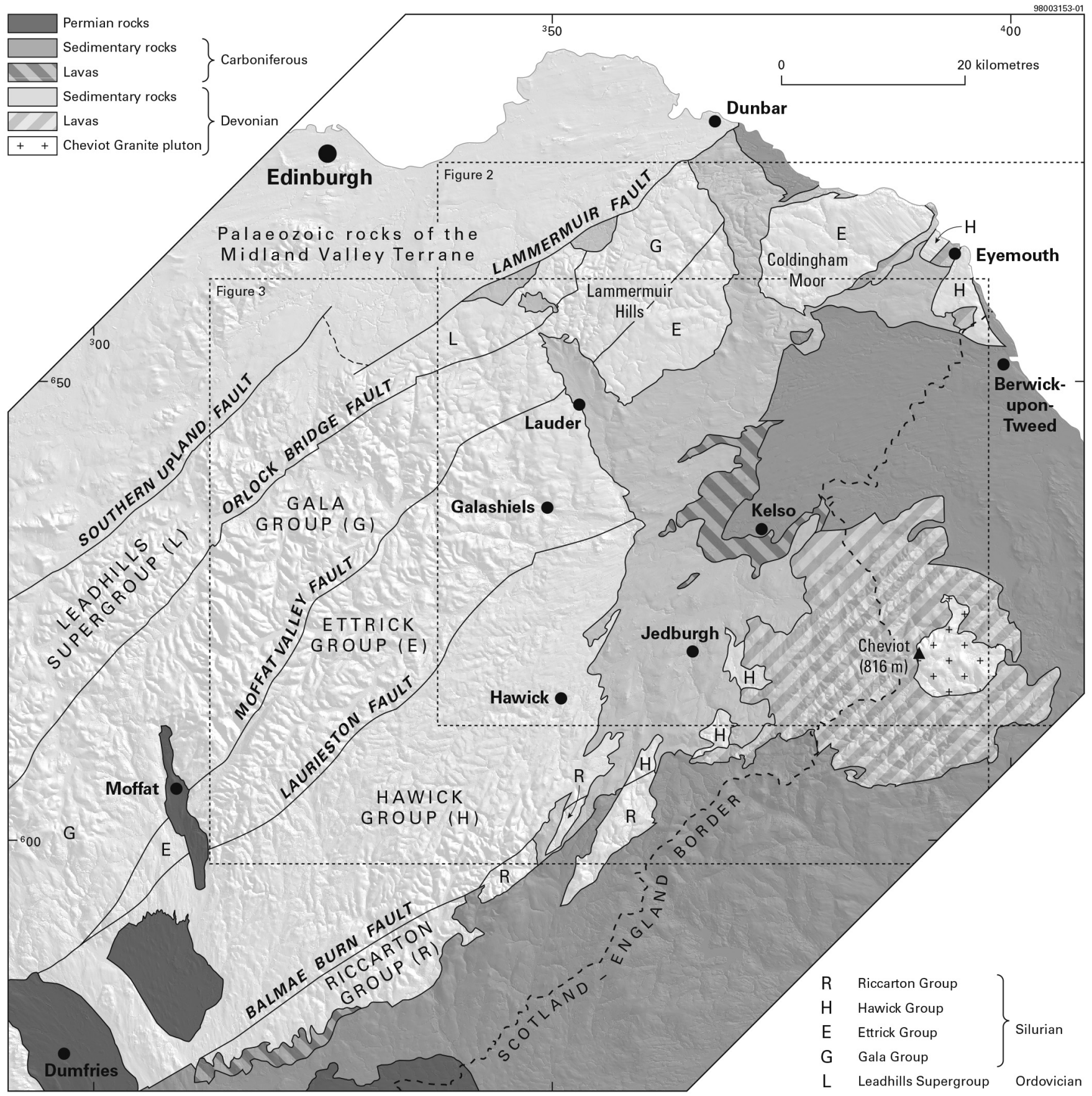




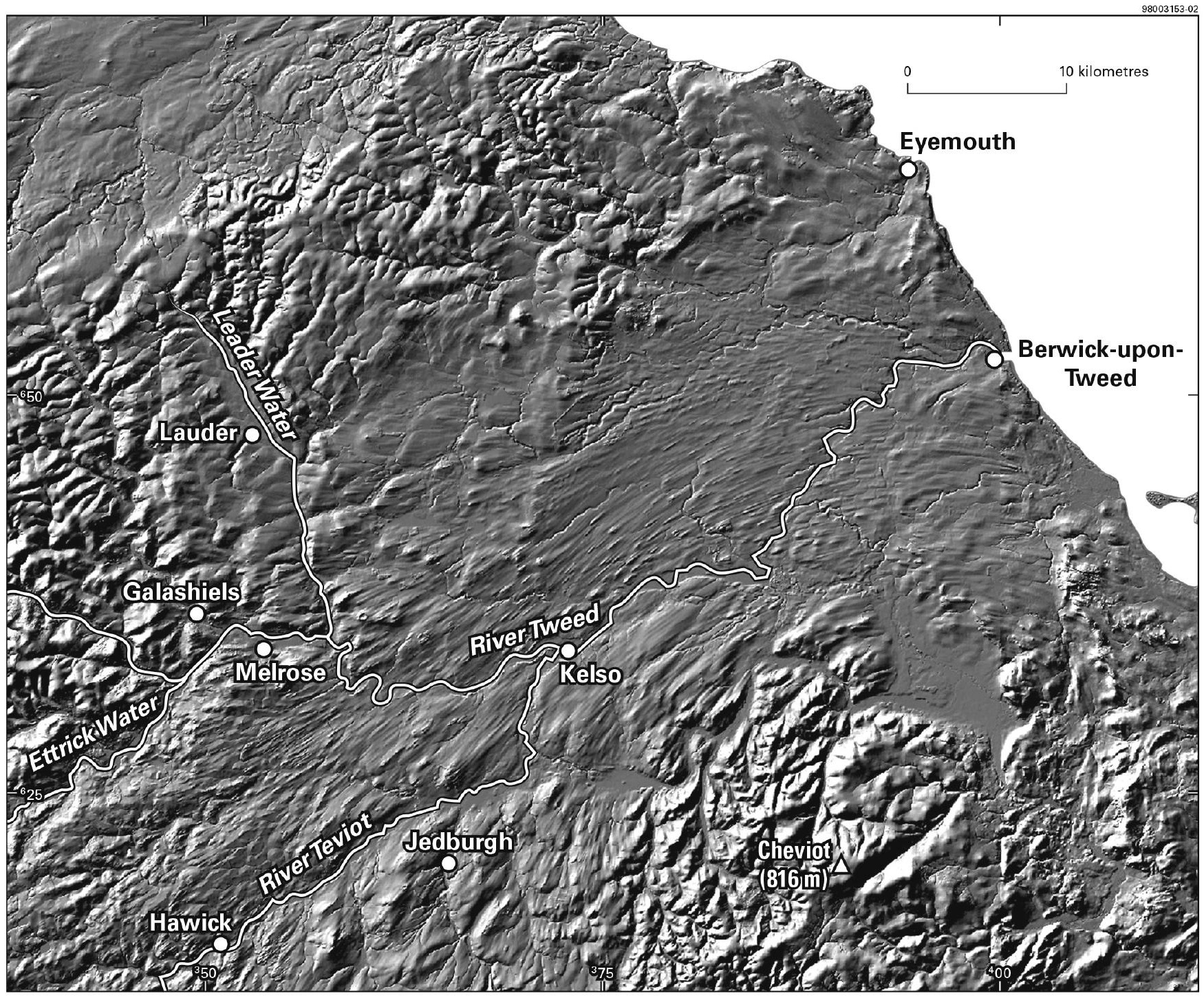


